\title{
INDIAN DOMESTIC SECTOR AND THE NEED FOR PROMOTING COMMUNITY BASED MICROGENERATION OVER STAND-ALONE SYSTEMS
}

\author{
Siddhartha Koduru' ${ }^{1}$, Madhumita Roy ${ }^{2}$ \\ ${ }^{1}$ Chitkara School of Planning and Architecture, Chitkara University, Rajpura, Punjab, India \\ ${ }^{2}$ Department of Architecture, Jadavpur University, Kolkata, West Bengal, India
}

\begin{abstract}
Urban growth has resulted in increasing demand for energy primarily in form of electricity. With depleting energy resources, growing concern for promotion of alternative energy sources urban housing is going through a transition phase. There is a greater need for promotion of on-site microgeneration systems at community level to ensure a near zero sustainable domestic sector. The paper tries to define three major concerns that need to be addressed in ensuring near zero housing communities - the first being understanding the character of existing renewable energy strategies and promoting them in the context of changing housing typologies, second, identifying the need for development of hybrid energy generation systems in conjunction with renewable energy systems to balance energy demand at times of climatic inconsistencies, the third concern being the integration of on-site microgeneration infrastructure within the context of the built environment without altering the existing character and aesthetics.
\end{abstract}

Keywords: Micro generation, Near Zero Housing Communities, Hybrid Energy Systems, Housing Typologies, Integrated Development

\section{INTRODUCTION}

Housing has become a necessity for human survival in urban areas. It is an individual's ability, viability and determination for survival in this urban world. India as other major developing countries has been experiencing an increase in urban growth, corresponding to this the urban population to total population of India ratio has increased from $20 \%$ in 1971 to $28 \%$ in 2001 and $31 \%$ in 2011 [1]. Till 1980-90 migration in search for a better quality of life had accelerated the growth in urban population, with time the dimensions of the urban areas have expanded through inclusion of periphery rural areas. In the past decade upgradation of small and medium towns has brought down the rate of migration but the urban population numbers are still on the rise. Population increase has put excessive pressure on urban infrastructure like transportation, housing, potable water, electricity and sanitation. If measures are not taken, lack of sufficient funds will impend provision of basic infrastructure required to meet the needs of about $60 \%$ India's population living in urban areas by 2030 [2].

Increasing housing demand in urban areas on the other hand has prompted private developers to take advantage of the situation by indiscriminately developing high rise high density housing projects both within the urban areas and their periphery. The varied household configurations within these housing projects have opened up options for people from varied economic classes and affordability levels, but without any consideration to the pressure created on both land and resources.
To attract the masses and also ensure affordability, these urban housing society developments are predominantly high rise in character and integrated with heavy energy intensive infrastructure setups which include lifts, fire safety systems, centralized air conditioning systems, electronic surveillance, etc., which are dependent on backup energy networks to compensate for power outages and failure of the power grid. The backup systems primarily comprise of generators which run on conventional fossil fuels like diesel or natural gas. The whole setup involves huge initial investment and recurring maintenance costs, which later on influences the monthly expenditure of households in these townships.

In the present age of growing energy crisis attempts are being made to reduce the demand side along with energy conservation at various levels, but the scale of implementation has not delivered desired results in domestic sector leading to energy insecurity. Also, user behaviour and varied age groups lead to diverse energy consumption patterns thereby challenging energy demand predictions. To meet the global carbon emission regulations along with the domestic sector energy demand India has to develop and promote decentralized energy generation systems within the scope of existing housing development so as to meet their operational energy demand along with user interaction based energy management to reduce energy wastage. 


\section{ENERGY SCENARIO OF INDIA}

India is the third largest energy consumer of the world after China and United States, followed by Russia and Japan with a significant growth in domestic energy demand after China in between 2010-2012. A major portion of electricity produced in India is by burning coal, diesel or gas in thermal power plants $(66.9 \%)$ or from hydro-energy projects (18.6). Nuclear power plants $(2.3 \%)$ contribute a very small portion
States generate over $40 \%$ of power in India; total installed base of $211,766 \mathrm{MW}$

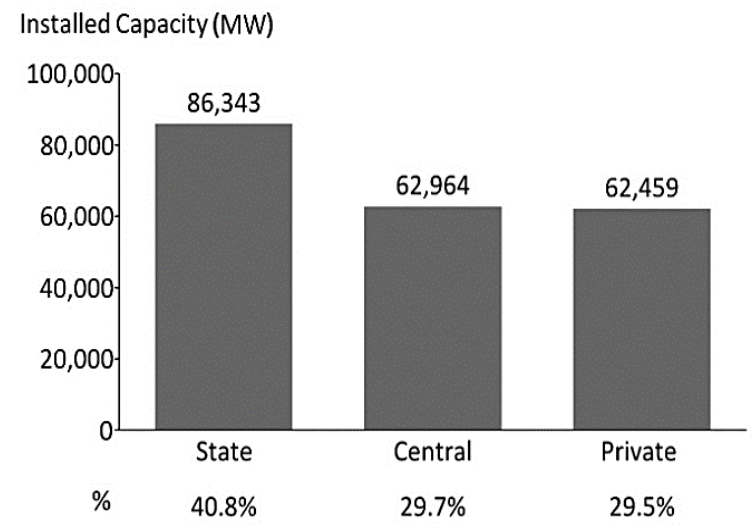

along with non-renewable and biomass based sources (12.2\%) (Fig.1) [3]. With non-renewable fuels as the primary source of power generation there has been an increase in import of coal and oil, also in the recent past accelerated development of hydro projects has resulted in major environmental disasters, causing extensive damage to life and property, as in case of June 2013 floods in Uttarakhand.

\section{Renewable Sources account for $12 \%$ of the installed} MW capacity

Installed Capacity (MW)

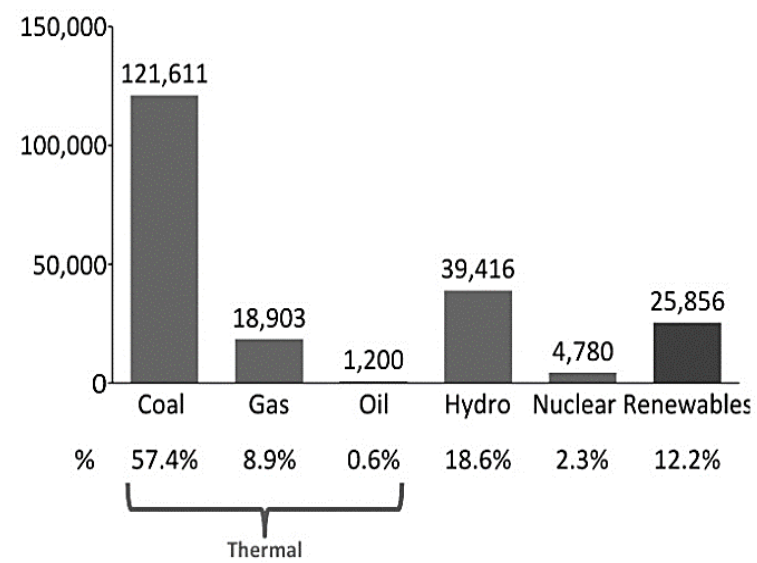

Fig 1 Power generation configuration of India

(Source: Ministry of New and Renewable Energy, Ministry of Energy; India and Rev Partners Analysis)

Nuclear power generation has observed a major boost in the past decade, but low uranium supplies and import restrictions due to pressure from global nuclear treaties are threatening the future maintenance and sustainability of these high infrastructure setups. The development of power projects based on alternative energy sources primarily solar and wind based technologies is still in its initial stage, and the present level of implementation has been possible through government subsidy, international pressure and sponsorship from other countries. Such alternate energy sources also lack easy acceptability by the community, owing to their efficiency rate primarily defined by the geological location and under developed technological inputs.

Indian power generation has significantly grown from around 1,362 Mega Watts (MW) to over 160,000 MW in between 1947 and mid of 2010, rating India as the third largest producer of power in Asia. Despite the growth in electricity over the years, there has also been an increase in energy deficit. Transmission and distribution losses based on choice of fuel source and location of various power generation sources contribute majorly to the energy deficit, making India rank as no. 1 in the world for transmission and distribution losses of total electricity produced (Fig.2). As a result of this between 2003, and 2010 the energy deficit reached a value of 9.1 percent, and the average-peak power deficit reached 12.8 percent.

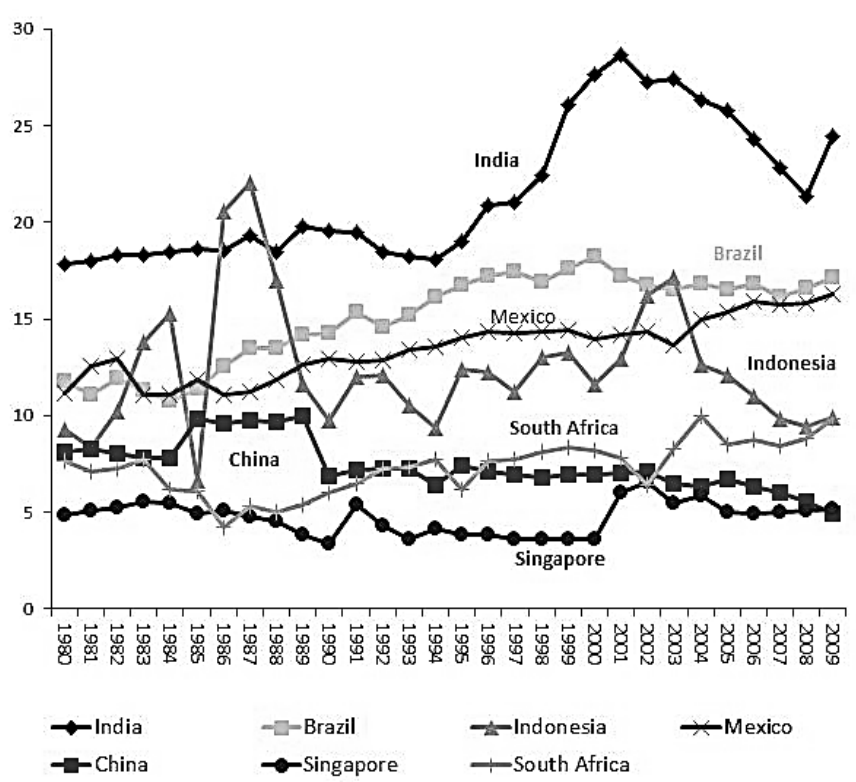

Fig 2 Global comparison of transmission and distribution losses as percent of power output

(Source: World Bank, World Development Indicators) 
It would be significant to consider the locational vulnerability of the existing energy infrastructures due to climate change and both natural and manmade disasters (Fig.3). As depicted in the map major portion of India is prone to disasters, and with time and human development interventions even the areas which are least expected area showing signs of vulnerability. Major hydro power projects have become cause for flooding of lower areas during monsoons, the vast expanse of coast line prone to cyclones pose a threat to both off shore and on shore wind energy systems, being a major seismic zone certain parts of India are periodically cut off from the rest of the country, adding to this climatic vulnerability and global influences add to all these problems.
Energy deficit and rising energy consumption have resulted in an increase in power outage frequency, duration and impact range affecting various sectors of the economy and overall GDP growth rate. The revenue loss due to this wastage has effected investment for development of new power generation projects and capacity additions in existing power projects [4]. As a result, present day power demand problems and failing infrastructure are threatening future energy demand projections, forcing the need to search for alternative energy sources which are ideally renewable in nature, decentralized to minimize transmission losses, localized so that they can be planned accordingly to locational vulnerability and community based to ensure participatory approach in setting up, upkeep and maintenance of such infrastructure.

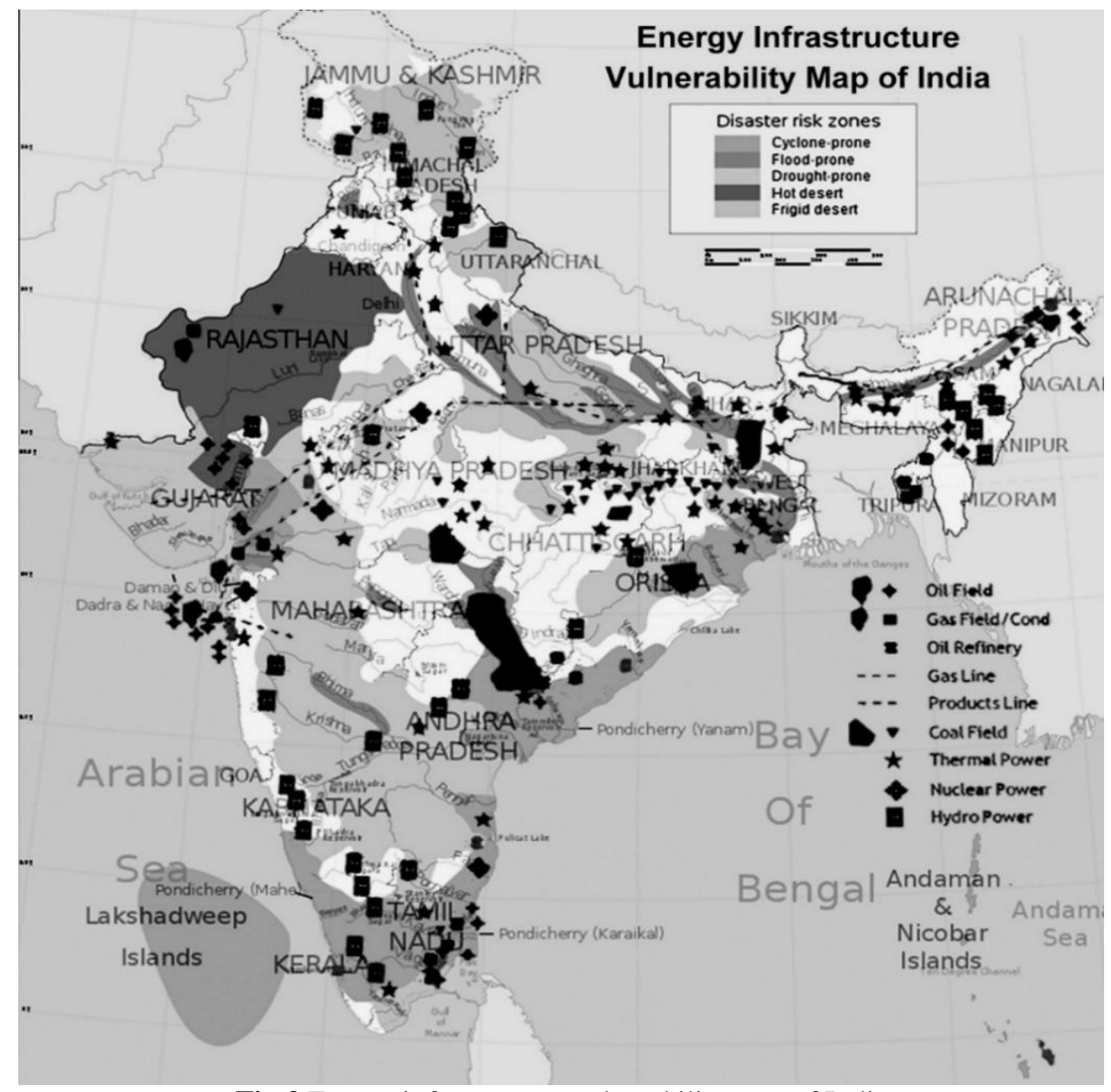

Fig 3 Energy infrastructure vulnerability map of India

(Source: Wikipedia and Live Journal)

\section{SCOPE OF RENEWABLE ENERGY IN} URBAN CONTEXT

Considering the scope of renewable energy available across diverse geographical configuration of India, the principle types available are - biomass, solar, hydro, wind, municipal waste, industrial waste, geothermal heat, tidal and wave energy. Within the context of urban housing the potential contributors are solar, wind and biomass based energy systems. Solar based heating and energy generation systems are already the most established in the form of solar water heating or solar photovoltaic (SPV) systems. Wind based energy systems are yet to find their place within the urban context due to the varied factors that include rising height of buildings, local factors impacting wind patterns, technical and financial feasibility. Though a lot of research is underway in enhancing the efficiency of both these technologies they are yet to find their full potential in 
implementation and integrated development within the context of urban housing to meet the growing energy demand. Biomass and municipal waste based energy systems have been limited primarily to pilot projects and in most cases they are non-operational owing to technical and financial issues.

If the solar potential is assessed the average solar energy incident of India is around 4 to $7 \mathrm{kWh} / \mathrm{m}^{2}$ and with around 1,200-1,800 sunshine hours per year varying on basis of location, the total energy generated could surpass the actual energy demand. Theoretically, the total solar energy output of India for a duration of about 300 clear sunny days in a year could reach up to $60,00,000 \mathrm{GW}$. The problems in meeting this production target range from availability of land for setting up solar array based power facilities, which demand around 250 acres of land for $20-60 \mathrm{MW}$ output.

Second, in the urban context where there is scarcity of land rooftops are the only available space for setting up solar based infrastructure, which again depends on the architectural character and disaster vulnerability of the place. The economics of setting up such infrastructure on an individual household basis when equated to total duration after which returns are derived are not quite promising for the end user as a result leading to demand in reducing the investment cost by provision of subsidies.

Though wind energy accounts for $67 \%$ of total grid interactive renewable energy in India in comparison to only $7 \%$ from solar based systems, most of the power generated is through off shore wind farms along the coast and inland areas of Gujarat and Rajasthan. The topography of India also offers least scope for setting up wind farms in the inland areas (Fig.4) with a major portion of northern regions falling under wind power density of 0-100 W/Sq.mts., thereby rendering it of least scope for microgeneration based strategies within urban areas.

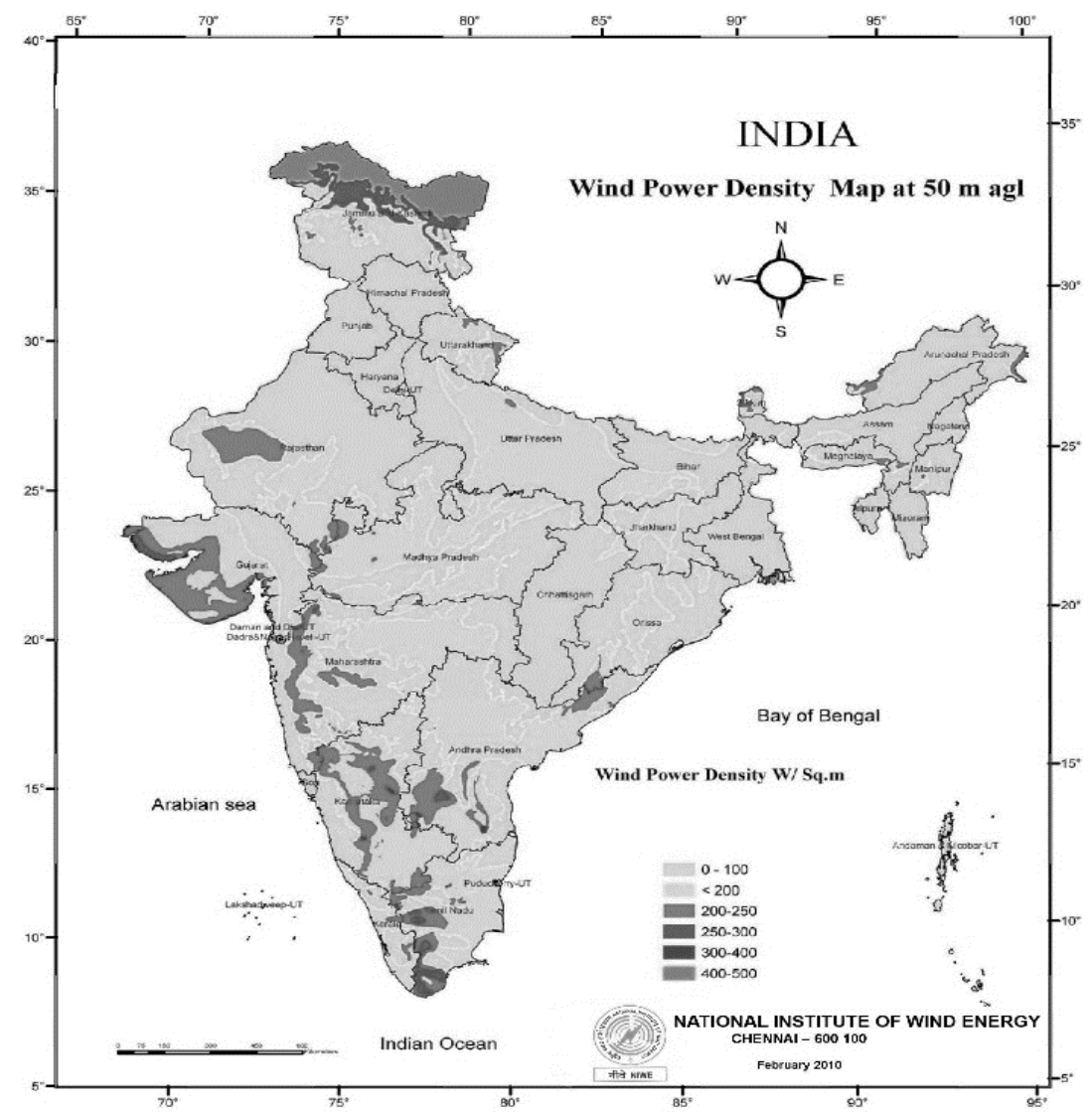

Fig 4 Wind power density map of India

(Source: Center for Wind Energy Technology, www.cwet.tn.nic.in)

Biomass and municipal waste based energy systems are viable due to the agrarian character of suburban areas around major urban centers which ensure availability of agricultural waste in addition to urban waste that could be converted into energy. Such energy systems have been a success in rural areas owing to the vast expanse of agricultural land and animal husbandry. But within the context of urban areas they have failed due to logistic reasons of delivery and storage of waste which otherwise have become centers of environmental degradation and health factors. The still immature and lower efficiency of the technology result in not generating optimum output in comparison to other renewable technologies, as a result most units have either been shut down or have become financial burdens for municipal authorities. In view of all these observations, solar based energy generation offers greater 
potential than other sources in housing sector, but integrating them into the physical built and ensuring social acceptance and financial viability need to be addressed.

\section{DOMESTIC ENERGY DEMAND AND}

\section{FUTURE TRENDS}

In the past three decades, Indian domestic sector has become the third major consumer of total energy produced through consumption of various fuels after industry and transport. In the year 2010-2011, industries consumed about $45 \%$ of total energy produced followed by the domestic sector with $22 \%$ consumption (Fig.5) with an increase of $8 \%$ annually. Trend analysis indicates that domestic sector has seen an increase of $9.67 \%$ electricity consumption in comparison to $5.57 \%$ by the industry from 1970-1971 to 2010-2011 [3].

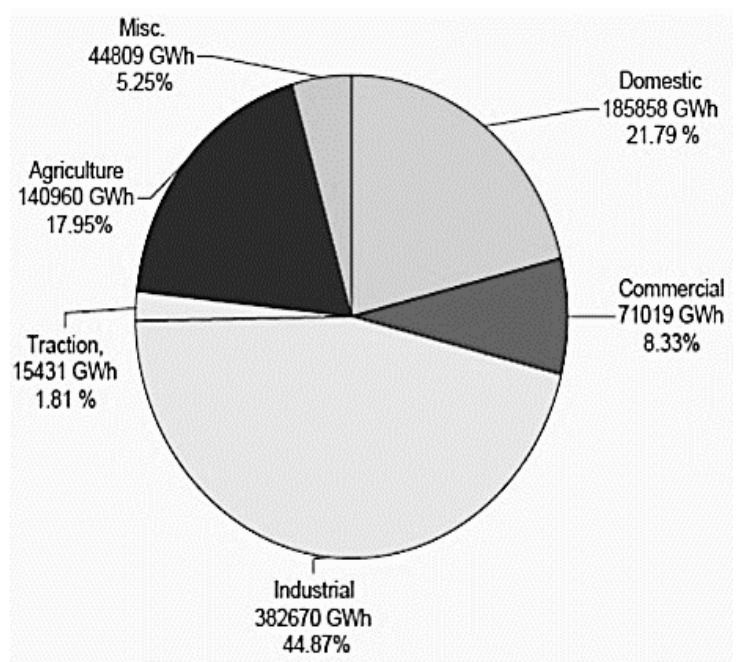

Fig 5 Sector wise electricity consumption pattern of India (Source: Central Electricity Authority, www.cea.nic.in)

Increasing global consciousness towards greenhouse gas emissions has pushed the need for promotion of alternative renewable energy sources in various sectors including the domestic sector, as it is the highest consumer of utility electricity and fossil fuels for heating, thereby contributing majorly towards increase in global carbon-di-oxide levels $[5,6]$.

The primary factors that contribute to the increase in domestic energy demand include sedentary lifestyle demanding continuous information exchange across various media and climatic change which influence the ownership of electrical appliances and their operating hours. Even though efforts are underway to increase their efficiency through development of energy labelling and smart networks the demand for power has been increasing. Power theft is another major deterrent in the upgradation of existing energy infrastructure leading to huge financial losses for power generation companies and in some states it has reached up to $30 \%$ of total power generated.

Gauging the future energy demand of urban households and defining a common threshold in housing energy demand and efficiency is quite challenge owing to varied user groups differing on basis of their age, financial status, occupation and lifestyle [14, 15]. The dynamic user behaviour and occasional surge in power demand during festivals, cricket matches and regional climatic disturbances result in volatile nature of energy demand within urban areas in comparison to more static energy demand of rural areas.

Promotion of centralized solar power plants to meet domestic energy demand involves high initial investment costs and dependence on geographical location and weather conditions. The cost of transmission and distribution losses result in increase of pre unit cost of power consumed. Also, the quantum of energy generated through such systems can operate low energy demanding appliances like general lighting, fans but high energy rated appliances like air conditioners or space heating equipment which are seasonal based need a different energy source. Such solar power projects also require vast land area in setting the infrastructure and viable in meeting energy demand of low energy users like a cluster of rural areas, and future increase in energy demand met through up-scaling of existing infrastructure.

\section{ISSUES WITH EXISTING SOLAR ENERGY BASED STRATEGIES IN VIEW OF CHANGING HOUSING TYPOLOGIES}

In the year 2005 residential spaces formed 16,300 Million sq.ft, which is about $78 \%$ of the total 20,882 Million sq.ft floor space area available, and it is projected that the residential area would increase to 69,823 Million sq.ft by 2030. In such a scenario, high rise high density gated housing development is the viable option in meeting future housing demand, which apart from ensuring affordable housing with increasing land price also promote a sense of security for the community living within these townships. With increasing affordability levels, varying lifestyles and job character housing typologies have undergone major transformation. Today's housing typologies could be classified into three categories - low rise - low density plotted development, low rise - high density row housing, high rise - high density townships.

Table 1 gives a broad overview of the issues concerning renewable energy infrastructure integration in these housing typologies based on their physical development, ownership pattern and present state of renewable infrastructure integration. 
Table 1 Issues concerning Renewable Energy Infrastructure integration in various Housing Typologies

\begin{tabular}{|c|c|c|}
\hline $\begin{array}{l}\text { Housing } \\
\text { Typology }\end{array}$ & $\begin{array}{l}\text { Issues concerning Reneu } \\
\text { Development, Ownership }\end{array}$ & $\begin{array}{l}\text { able Energy Infrastructure integration with respect to Physical } \\
\text { nd Existing Renewable Technologies }\end{array}$ \\
\hline \multirow{3}{*}{$\begin{array}{l}\text { Low Rise } \\
\text { Low Density } \\
\text { Plotted } \\
\text { Development }\end{array}$} & $\begin{array}{l}\text { Physical Development } \\
\text { Character }\end{array}$ & $\begin{array}{l}\text { - Individual households with front and rear setback or on all sides. } \\
\text { - Maximum three floors } \\
\text { - Varying architectural character }\end{array}$ \\
\hline & Ownership & $\begin{array}{l}\text { - Single owner with multifamily occupancy } \\
\text { - Owner with single or multiple tenant occupancy }\end{array}$ \\
\hline & $\begin{array}{l}\text { Existing character of } \\
\text { Renewable Technologies }\end{array}$ & $\begin{array}{l}\text { - Ample space per household for renewable energy strategies } \\
\text { - Individual user based solar water heating systems on roof }\end{array}$ \\
\hline \multirow{3}{*}{$\begin{array}{l}\text { Low Rise } \\
\text { High Density } \\
\text { Row Housing } \\
\text { with Floor } \\
\text { Wise } \\
\text { Ownership }\end{array}$} & $\begin{array}{l}\text { Physical Development } \\
\text { Character }\end{array}$ & $\begin{array}{l}\text { - Low density gated community comprising of row housing } \\
\text { - Primarily front and rear setback with common walls } \\
\text { - Maximum three floors } \\
\text { - Uniform architectural character within community }\end{array}$ \\
\hline & Ownership & $\begin{array}{l}\text { - Floor wise ownership } \\
\text { - Owner or tenant based occupancy } \\
\text { to Ownership of terrace varies - treated as common area or rights given } \\
\text { to owner with the terrace as roof }\end{array}$ \\
\hline & $\begin{array}{l}\text { Existing character of } \\
\text { Renewable Technologies }\end{array}$ & $\begin{array}{l}\text { - Varies on basis of terrace ownership } \\
\text { - Individual or multi user solar water heating systems on roof }\end{array}$ \\
\hline \multirow{3}{*}{$\begin{array}{l}\text { High Rise } \\
\text { High Density } \\
\text { Townships }\end{array}$} & Development & $\begin{array}{l}\text { - High density gated community comprising of high rise towers } \\
\text { - Clear distance between each block as per developmental controls } \\
\text { - Minimum } 4 \text { floors and maximum } 16 \text { floors } \\
\text { - Uniform architectural character within community }\end{array}$ \\
\hline & Ownership & $\begin{array}{l}\text { - Flat wise ownership } \\
\text { - Owner or tenant based occupancy } \\
\text { right with owner in case of penthouse }\end{array}$ \\
\hline & $\begin{array}{l}\text { Existing character of } \\
\text { Renewable Technologies }\end{array}$ & $\begin{array}{l}\text { - Varies on basis of terrace ownership } \\
\text { - Less open terrace space per household due to provision of service } \\
\text { areas for water tanks, lifts, staircase and ducts } \\
\text { - Difficult to meet demand of all households even after installation of } \\
\text { multi user solar water heating systems }\end{array}$ \\
\hline
\end{tabular}

Provision of roof based solar water heating systems accounts for the most common renewable energy strategy being employed in the above housing typologies. Scope of SPV or BIPV systems in domestic sector has to be explored and their implementation strategies detailed out. Existing energy conservation and domestic level renewable energy generation initiatives that are being employed in the above typologies are only definitive with the solutions being generalized and loaded with incentives, in such a complex domestic setup a generalized solution may have low rate of success owing to variable character of factors affecting energy demand of households [7]. 
Energy metering slabs have been undergoing revision across various states of India and at present the slabs for calculating monthly domestic electricity charges range from up to 100 units, $101-300$ units, 301-500 units and above 501 units. The average per unit rate across various states range from 4.25-5.00 rupees per unit for up to 300 units and increases to $6.25-9.50$ rupees per unit for above 400 units

Considering the average energy consumption of a 106 sq.mts, 4 member individual household with a connected load of $4.8 \mathrm{~kW}$ being around $320-500 \mathrm{kWh}$ per month. The annual energy consumption of the household ranges from $3,840-6000 \mathrm{kWh}$ and the monthly electricity costs could range between $1,450-4,000$ rupees across various states. Considering the floor area equal to roof area of 106 sq.mts, a solar roof energy system of $4 \mathrm{~kW}$ with multiple PVs of $16 \%$ efficiency covering 25 sq.mts each under ideal conditions can generate a power of $1,500-2,200 \mathrm{kWh}$ per month (as per calculations by NREL web tool). This is more than enough to meet the requirements of a three storied $(\mathrm{G}+2)$ housing unit, but beyond this there would be a need for energy input from the grid.

Also present approach towards solar based strategies are driven by incentives. Incentives in the form of subsidies do not reach every level of the housing structure owing to location, administrative and information transfer issues, this invariably gives scope for middle men to take advantage if there is lack of transparency in the whole system [8,9]. Any incentive should be based on the household energy saving output rather than on the input for energy generating infrastructure. This would ensure incentives administered by government to those potential households which have achieved desired targets, leading to better awareness and information transfer at the household level [10, 11, 12].

\section{DEFINING THE NEED AND SCOPE OF COMMUNITY LEVEL MICROGENERATION BASED MICRO GRIDS IN HOUSING}

The attempt of any alternative approach should be to reduce the burden of monthly energy expenditure on a household, for which a decisive approach needs to be worked out searching for alternative implementation strategies that would promote energy generation as well as conservation without compromising on the true energy needs of a household. Such power generation initiatives shall define the future pathways for promotion of sustainable energy generation, and also lead to significant job creation than centralized projects. Household based microgeneration at community level can be a viable option for it allows housing society or communities to generate their own power and any excess production could be transferred to the grid in return for incentives or credit [7,8]. At times of need or in case of low production rate the supply from grid could compensate for the deficit and paid back through credits or bills. This results in a dual channel approach that is very dynamic and ensure a near zero housing development.
Solar based systems can meet the demand for plotted and low rise low density row housing development if the true potential of the roofs is exploited. But in case of high rise high density townships the energy demand surpasses the production through roof based solar based energy systems. To enhance energy production and ensure a near zero housing development the potential of Building Integrated Photovoltaic Systems (BIPV) need to be investigated along with development of hybrid energy systems. Hybrid energy systems are energy networks that offer greater flexibility and potential to cover up deficit in energy production primarily due to climatic factors.

Similar to stand alone systems the hybrid systems can sell out additional generated power thereby reducing or completely eliminating central grid dependency, but also reduce transmission losses resulting in grid stability and less power outages. The operation of such units shall aid in meeting energy demand at times of grid failure due to disasters, as has been demonstrated in numerous international scenarios like the successful case of Sendai micro grid being operational during the March 2011 earthquake and subsequent tsunami in Japan.

Hybrid energy generation systems within housing development could either function as stand-alone facilities or integrated into a single network with solar based infrastructure forming the major component. The other components of such multiple energy generation systems within the context of urban housing could be ground and air source heat pumps or Combined Heat and Power (CHP) systems based on biomass, natural gas or traditional fuels [16].

Further research is required to understand the integration of various hybrid infrastructure into the physical structure of existing housing with respect to their siting and provision of access for their maintenance. Studies would also be required to understand the impact of hybrid infrastructure integration on built form aesthetics, as it has been observed that most renewable energy technologies are installed after the overall planning and construction of any built form is undertaken, resulting in their functional reasons based integration without any consideration on aesthetics [17].

The research shall aid in defining guidelines and provision in byelaws for the promotion of renewable energy infrastructure through built form integrated development for under construction and future housing. Decentralized energy generation networks in form of building integrated microgeneration and hybrid technologies could be an effective way of ensuring energy efficiency and meeting the near zero energy target in housing.

\section{CONCLUSION}

There is a greater need for promotion of household and community based microgeneration in meeting the increasing energy demand with reduced carbon emissions. The financial model for output based incentives that can aid in better promotion and involvement of the community 
towards renewable energy systems needs to be investigated. There is a highlighted need to search for hybrid energy systems rather than pure renewable energy based systems to meet energy demand at times of climatic and local inconsistencies. Further research has to be undertaken for promotion of built environment integrated microgeneration so as to meet energy demand targets without compromising on aesthetics and character of the built forms.

\section{REFERENCES}

[1] Census of India 2011

[2] Report of the subcommittee on financing urban infrastructure in the 12th plan. High level committee on financing infrastructure, Ministry of urban development, Government of India, March 2012

[3] Power Scenario at a Glance, Central Electricity Authority, Planning Wing, Integrated Resource Planning Division, Ministry of Power, Government of India, July 2010

[4] Energy Statistics 2012. Central Statistics Office, National Statistical Organisation, Ministry of Statistical and Programme Implementation, Government of India

[5] Stephane de la Rue du Can, Virginie Letschert, Michael McNeil, Nan Zhou, and Jayant Sathaye. Residential and Transport Energy Use in India: Past Trend and Future Outlook, Environmental Energy Technologies Division, Ernest Orlando Lawrence Berkeley National Laboratory, January 2009

[6] Gevorg Sargsyan, Mikul Bhatia, Sudeshna Ghosh Banerjee, Krishnan Raghunathan, Ruchi Soni. Unleashing the Potential of Renewable Energy in India, South Asia Energy Unit, Sustainable Development Department, The World Bank, 2010

[7] Microgeneration, Global Energy Advisory. http://www.globalenergyadvisory.com/component/rs files/view?path=Brochures/microgeneration.pdf

[8] Energy Subsidy Reform: Lessons and Implications, International Monetary Fund. http://www.imf.org/external/np/pp/eng/2013/012813 .pdf

[9] Gennaioli, C and M Tavoni. "Clean or 'Dirty' Energy; Evidence on a Renewable Energy Resource Curse", FEEM working paper, 2011

[10] Analysis of the Scope of Energy Subsidies and Suggestions for the G-20 Initiatives. IEA, OPEC, OECD, World Bank Joint Report, Prepared for submission to the G-20 Summit Meeting, Toronto, 26-27 June 2010. http://www.oecd.org/env/45575666.pdf

[11] Customer Incentives for Energy Efficiency through Electric and Natural Gas Rate Design, A Resource of the National Action Plan for Energy Efficiency, U.S. Environmental Protection Agency, September 2009.

http://www.epa.gov/cleanenergy/documents/suca/rat e_design.pdf

[12] Utility Incentives for Demand Response and Energy Efficiency, http://www.enernoc.com/our-resources/138- resources/white-papers/592-utility-incentives-fordemand-response-and-energy-efficiency

[13] John Eakins. An Analysis of the Determinants of Household Energy Expenditures: Empirical Evidence from the Irish Household Budget Survey. Degree of Doctor of Philosophy in Economics from the University of Surrey, Surrey Energy Economics Centre (SEEC), School of Economics, University of Surrey, May 2013

[14] Liu, J., R. Wang, and J. Yang. Metabolism and driving forces of Chinese urban household consumption. Population and Environment 26(4), 2005, pp. 325-341.

[15] James Keirstead. Selecting sustainability indicators for urban energy systems, International Conference on Whole Life Urban Sustainability and its Assessment, Glasgow, 2007

[16] Renewable Energy: Investing in Energy and Resource Efficiency. Green Economy series, UNEP, 2011http://www.unep.org/greeneconomy/Portals/88/ documents/ger/GER_6_RenewableEnergy.pdf

[17] Making Sense of Renewable Energy Technologies: Opportunities for Business. Carbon Trust, March 2012.

http://www.carbontrust.com/media/63632/ctg011renewable-energy-technologies.pdf 